EGU21-13525, updated on 06 Mar 2021

https://doi.org/10.5194/egusphere-egu21-13525

EGU General Assembly 2021

(c) Author(s) 2021. This work is distributed under

the Creative Commons Attribution 4.0 License.

\title{
Computing slope length (USLE): return to original definitions.
}

Antonio Saa-Requejo, Pablo Sevilla, Ana María Tarquis, and Anne Gobin

CEIGRAM. UPM., Edafología y Climatología, Madrid, Spain (antonio.saa@upm.es)

Soil erosion is an important process of consideration in different erosion risk models and in planning soil conservation. Common erosion models, such as the USLE and its derivatives are widely used. In this context, the slope length is the variable with the most difficulties due to the different scales and procedures available that lead to very different results. Furthermore, many of the calculation procedures are based on a hydrological network definition that poses many problems in areas with a complex topography.

We propose an algorithm implemented in GIS, returning to the original field perspective form defined by the USLE and RUSLE, which is detached from the hydrological network definition. The calculation procedure is based on $5 \mathrm{~m}$ DEM and defines overland water flow at the field scale.

This method has been applied in three areas with different climate and geomorphology. The results are similar to those derived from aerial photograph observation.

\section{References}

Honghu Liu, Jens Kiesel, Georg Hörmann, Nicola Fohrer. (2011). Effects of DEM horizontal resolution and methods on calculating the slope length factor in gently rolling landscapes. Catena, $87,368-375$

Renard, K.G., Foster, G.R., Weesies, G.A., Mc. Cool, D.K y Yoder, D.C. (1997). Predicting Soil Erosion by Water: A Guide To Conservation Planning With The Revised Universal Soil Los Equation. Agricultural Handbook 703. USA: US Department of Agriculture.

\section{Acknowledgements}

Authors are grateful to Authors are grateful to Agroseguro funding this research. 